Anđela LJUBIĆ ČOVIĆ

doktorandica Pravnog fakulteta Sveučilišta u Mostaru

Općinski sud Čitluk

andjela.ljubic@gmail.com
UDK: 347.235.11(497.6)

Izvorni znanstveni rad

Primljen: 15. 7. 2020

Prihvaćen: 30. 7. 2020.

\title{
ODGODA POVJERENJA U ZEMLJŠNE KNJIGE U BOSNI I HERCEGOVINI?
}

Sažetak: Završne odredbe entitetskih zakona o stvarnim pravima pozivaju/nalažu vanknjižnim nositeljima stvarnih prava na nekretninama da u tamo propisanim rokovima upišu svoja prava na nekretninama, te određuju da rokovi za podizanje brisovne tužbe počinju teći tek od stupanja na snagu tih zakona. Ove odredbe moguće je, a usporedno pravno i utemeljeno, tumačiti kao odgodu učinaka pravila o povjerenju u zemljišne knjige. S druge strane, u entitetima je prije donošenja Zakona o stvarnim pravima, zakonima o zemljišnim knjigama predviđena zaštita stjecanja stvarnih prava na nekretninama temeljem povjerenja u zemljišnu knjigu, a da istovremeno tim zakonima nije ostavljen prijelazni rok za usuglašavanje zemljišnoknjižnog s izvanknjižnim, stvarnim stanjem prava na nekretninama, u kojem ne bi vrijedili učinci povjerenja u zemljišne knjige. Otuda se čini proturječnim da načelo povjerenja u zemljišne knjige djeluje u razdoblju nakon usvajanja Zakona o zemljišnim knjigama a do stupanja na snagu Zakona o stvarnim pravima, a nakon toga da su njegovi učinci suspendirani. Ovaj rad analizira potencijalne prepreke nastupanju učinaka povjerenja u zemljišne knjige u entitetima i Brčko distriktu BiH (kao što je npr. postupak uspostavljanja zemljišne knjige/katastra nekretnina/registra zemljišta), te pokušava dokazati da u BiH, od stupanja na snagu reformiranog zemljišnoknjižnog zakonodavstva, nije (izuzev u RS-u u odnosu na nekretnine u društvenom vlasnišstvu u razdoblju 2010. - 2011.) ni bilo odgođeno djelovanje povjerenja u zemljišne knjige.

Ključne riječi: povjerenje u zemljišne knjige, odgoda povjerenja, uspostavljanje zemljišne knjige. 


\section{Uvodne napomene}

$\mathrm{U} \mathrm{BiH}$, unatoč kontinuiranom napretku u tom pravcu, ${ }^{1}$ zemljišnoknjižno i vanknjižno stanje nekretnina i prava na nekretninama su neusklađena; kaže se da je zemljišna knjiga nesređena, neažurna. Razlog tomu leži u više međusobno povezanih utjecaja, koji u većem dijelu generiraju iz ranije pripadnosti bosanskohercegovačkog (stvarnog) prava krugu socijalističkih pravnih poredaka, gdje je zemljišna knjiga kao evidencija stvarnih prava na nekretninama bila lišena svoje temeljne uloge. ${ }^{2}$

Transformacija stvarnog prava u $\mathrm{BiH}$, s ciljem reintegriranja u srednjoeuropski pravni poredak ${ }^{3}$ započela je početkom 2000 -ih godina, ${ }^{4}$ da bi, krećući se sporijim korakom u entitetima (dalje FBiH i RS), kulminaciju dosegla donošenjem entitetskih zakona o stvarnim pravima. ${ }^{5}$ Načelo povjerenja u zemljišnu knjigu eksplicitno je normirano u svim mjerodavnim propisima, u svim trima legislativnim jedinicama, bez obzira na odabrani način publiciranja prava na nekretninama

$1 \quad$ Projekt registracije zemljišta koji je pokazao rezultate u pogledu postizanja veće ažurnosti zemljišne knjige (v. Povlakić, M.: „Roll-back“ u nekim oblastima privatnog prava u Federaciji $\mathrm{BiH}$, u Nova pravna revija, Specijalni prilog petogodišnjeg izdanja časopisa, 2015. godina, Sarajevo).

2 U zemljišnoj knjizi nisu se provodile sve stvarnopravne promjene na nekretninama, upisi nisu vršeni u skladu sa zemljišnoknjižnim pravilima, načelo povjerenja u zemljišnu knjigu primjenjivano je s mnogo izuzetaka. Vidi u: Josipović, T.: Zemljišnoknjižno pravo u doba uključenosti u socijalistički pravni krug, u: Gavella, N., et.al., Hrvatsko građanskopravno uređenje i kontinentalnoeuropski pravni krug, Zagreb, 2005., str. 140. - 156. Stanković, O., Orlić, M.: Stvarno pravo, Naučna knjiga, Beograd, 1982., str. 333., Rn 1057.

3 Više u: Povlakić, M.: Transformacija stvarnog prava u Bosni i Hercegovini, Pravni fakultet Univerziteta u Sarajevu, 2009., str. 76., i dr., te u Gavella, N., et.al., Hrvatsko građanskopravno uređenje i kontinentalnoeuropski pravni krug, Zagreb, 2005., str. 181. i dalje.

$4 \quad \mathrm{U}$ Brčko distriktu $\mathrm{BiH}$ (dalje $\mathrm{BD} \mathrm{BiH}$ ) doneseni su Zakon o vlasništvu i drugim stvarnim pravima (Službeni glasnik BD BiH br. 11/01, 8/03, 40/04 i 19/07; dalje ZV BD BiH), Zakon o registru zemljišta i prava na zemljištu $\mathrm{BD} \mathrm{BiH}$ (Službeni glasnik BD BiH broj 11/2001, 1/2003, 14/2003, 19/2007, 2/2008; dalje ZRZPZ BD BiH). U entitetima su stupili na snagu Zakon o zemljišnim knjigama (Službene novine FBiH broj 58/02, 19/03 i 54/04), dalje ZZK FBiH; te Zakon o zemljišnim knjigama (Službene novine RS broj 67/03, 46/04, 109/05 i 119/08), dalje ZZK RS. U RS-u je kasnije izmijenjen način publiciranja prava na nekretninama na način da je zemljišnoknjižna evidencija zamijenjena katastrom nekretnina: Zakon o premjeru i katastru RS, Službeni glasnik RS, broj 6/12, 110/16, 62/18; dalje ZPK RS.

5 Zakon o stvarnim pravima RS (Službeni glasnik RS, broj 124/2008, 3/2009, 58/2009, 95/2011, 60/2015 i 107/2019.; dalje: ZSP RS); Zakon o stvarnim pravima FBiH (Službene novine br. 66/2013, i 100/2013, dalje: ZSP FBiH). 
(čl. 55. i 56. ZSP FBiH/RS, čl. 9. ZZK FBiH/RS, čl. 8. ZRZPZ BD BiH, čl. 34. ZV $\mathrm{BD} \mathrm{BiH,} \mathrm{čl.} \mathrm{56.} \mathrm{ZPK} \mathrm{RS).}$

\section{Načelo povjerenja u zemljišne knjige}

Eksplicitno reguliranje načela povjerenja u zemljišne knjige u stvarnopravnom (i zemljišnoknjižnom) poretku je od velike važnosti u reafirmiranju zemljišnoknjižne evidencije prava na nekretninama. ${ }^{6} \mathrm{U}$ uvjetima tržišnog gospodarstva, brz i jednostavan promet nekretninama je svojevrsni conditio sine qua non, a takav promet nekretninama je nezamisliv bez javne evidencije nekretnina i prava na nekretninama, za koju pravni sustav jamči da je točna i potpuna, te štiti stjecatelja prava na nekretnini koji se pouzdao u točnost i potpunost te evidencije. Naime, za pravno stanje nekretnine koja može biti u pravnom prometu mjerodavno je isključivo ono što je upisano u zemljišnoj knjizi. Jamčenjem istinitosti i potpunosti zemljišnoknjižnih upisa poredak konstituira na strani stjecatelja legitimno očekivanje da će, ako pristupe određenoj transakciji pravom na nekretnini u odnosu na upisanog titulara, upisom steći namjeravano pravo u onom sadržaju i opsegu koji je bio publiciran u zemljišnoj knjizi, čak i kad se publicirano stanje razlikuje od izvanknjižnog. Tako, načelo povjerenja djeluje u dva smjera - pozitivnom, kao načelo povjerenja $\mathrm{u}$ istinitost, i u negativnom, kao načelo povjerenja u potpunost. ${ }^{8}$

Imajući u vidu stanje zemljišne knjige u $\mathrm{BiH},{ }^{9}$ eksplicitno propisivanje stjecanja stvarnih prava temeljem povjerenja u zemljišnu knjigu bio je hrabar potez zako-

6 U radu će za označavanje evidencije prava na nekretninama biti korišten termin zemljišna knjiga kao opći termin budući da odgovara funkcijama svih publicitetnih evidencija u $\mathrm{BiH}$. Tamo gdje su rješenja različita u ovisnosti o evidenciji prava na nekretninama, ukazat će se na različitosti.

$7 \quad$ Gavella, N. et.al: Stvarno pravo, Svezak 1, Narodne novine, 1998., str. 198.

$8 \quad$ Positiver und negativer Vertrauensschutz; Richtigkeit und Vollstäntigkeit des Grundbuch; Sve što je upisano u zemljišnu knjigu postoji, a što nije upisano ili je izbrisano, ne postoji. Baur, F., Baur, J und Stürner, R.: Sachenrecht, 18., neu bearbeitete Auflage, Verlag C. H. Beck München, 2009., \$23, str. 303., Iro, G: Bürgerliches Recht IV, Sachenrecht, 2. überarbeitete Auflage, Springer, Wien - New York, 2002., str. 44. - 45. Raff, M. J., German real property law and the conclusive land title register. PhD thesis, Faculty of Law, The University of Melbourne, neobjavljeno, str. 317.

9 Poseban vid neažurnosti zemljišne knjige u $\mathrm{BiH}$ je to što je na samo cca $12 \%$ teritorija zemljišna knjiga bazirana na podacima tzv. novog premjera (podatak iz 2006. god.; usp. Mutapčić, H., Brkić; A.: Odnos normativnog i stvarnog stanja upisa prava na nekretninama u zemljišnu knjigu u Bosni i Hercegovini, s osvrtom na uporedno zakonodavstvo, Zbornik radova: Međunarodna naučna konferencija „Javni i privatni aspekti nužnih pravnih reformi u BiH: Koliko daleko možemo ići?,“ Tuzla, 2014., str. 153.). 
nodavaca, s obzirom na posljedice koje zaštita stjecanja temeljem povjerenja $u$ zemljišne knjige ima po izvanknjižna prava na nekretninama. Otuda bi sasvim logično i razumljivo bilo propisati odgođeno djelovanje povjerenja u zemljišne knjige. Ali bilo bi bitno učiniti to pravodobno. Zbog nesimultanog donošenja Zakona o zemljišnim knjigama i Zakona o stvarnim pravima u entitetima, kad su zakoni o zemljišnim knjigama po prvi put eksplicitno normirali načelo povjerenja u zemljišne knjige i učinili u tom pravcu zaokret u reguliranju instituta u odnosu na njegovu raniju primjenu u $\mathrm{BiH}$, a zakoni o stvarnim pravima doneseni $\mathrm{s}$ do deset godina zakašnjenja, učinci odgode povjerenja u zemljišnu knjigu morali su biti propisani ranijim zakonima, odnosno zakonima o zemljišnim knjigama. $\mathrm{Na}$ taj način bi se građani, pravne osobe, javnopravni subjekti, generalno svi titulari prava na nekretninama upoznali s tim da se u sustav uvodi načelo po kojem se pruža zaštita trećim osobama koje stječu stvarna prava na nekretninama, i to tako da će te treće osobe po upisu steći namjeravano pravo, čak i ako ga izvode iz nevaljanog prednikovog upisa, a steći će ga neopterećenog tuđim pravima, teretima i ograničenjima, koji, iako su postojali, nisu bili upisani u zemljišnoj knjizi. S tim ciljem, propisivanje odgode povjerenja u zemljišne knjige redovno prate i odredbe kojima se pozivaju vanknjižni nositelji prava na nekretninama da upišu svoja izvanknjižno postojeća prava na nekretninama u razdoblju za koje je propisana odgoda povjerenja. ${ }^{10}$ Odgoda učinaka pravila o povjerenju u zemljišne knjige povezana je i s postupcima uspostavljanja zemljišne knjige/katastra nekretnina/registra zemljišta, tamo gdje evidencija prava na nekretninama već postoji, ali nije ažurna, jer je u razdoblju dok traju ovi postupci potrebno zaštititi izvanknjižne titulare prava na nekretninama od nastupa posljedica stjecanja stvarnih prava temeljem povjerenja u zemljišnu knjigu. Na to se nadovezuju i odredbe o nevaženju pretpostavke točnosti zemljišne knjige u pogledu činjeničnog stanja nekretnine ako je zemljišna knjiga uspostavljena temeljem podataka starog premjera (čl. 55. st. 1. ZSP FBiH/RS).

\section{Odgoda povjerenja u zemljišne knjige: svrha}

Odgođeno djelovanje povjerenja u zemljišnu knjigu znači da se, u roku koji određuju zakoni koji inače reguliraju stjecanje stvarnih prava temeljem povjerenja u zemljišne knjige (to su zakoni o stvarnim pravima i zakoni o zemljišnim knjigama/javnim evidencijama), ne primjenjuju pravila o zaštiti povjerenja u istinitost $\mathrm{i} / \mathrm{ili}$ potpunost zemljišne knjige, odnosno da se zemljišnoknjižno stanje $u$ 
određenom razdoblju i u odnosu na neke (ili sve) nekretnine ne smatra točnim. Dakle, kad normiraju odgodu povjerenja u zemljišnu knjigu, ovi zakoni propisuju da zemljišna knjiga/javna evidencija nekretnina odražava istinito i potpuno stanje prava na nekretninama, ali istodobno propisuju da su za određeno razdoblje učinci povjerenja u zemljišnu knjigu - suspendirani. Smisao propisivanja odgođenog djelovanja povjerenja u zemljišne knjige je omogućavanje „prijelaznog roka" u kojem se izvanknjižnim nositeljima prava na nekretnini omogućuje da svoja prava upišu, a nevaljane upise brišu, odnosno da stanje zemljišne knjige učine točnim, jer to nakon isteka prijelaznog roka više neće moći učiniti ako pravo na nekretninama, pouzdajući se u sadržaj zemljišne knjige (iako je pogrešan), stekne savjesna treća osoba. U tom prijelaznom razdoblju ni prema kome, pa niti prema bona fides stjecateljima, ne djeluje neoboriva pretpostavka o istinitosti/ potpunosti zemljišnoknjižnog stanja. ${ }^{11}$

Kod odgode povjerenja u istinitost, neovisno o tome je li stjecatelj bio savjestan ili ne, njegovo je stjecanje moguće osporavati zbog toga što je u korist njegova prednika bio proveden nevaljan upis, jer je odgođena zaštita povjerenja u istinitost. Nositelji knjižnih prava koji su oštećeni nevaljanim upisom dok traje odgoda zaštite povjerenja $u$ istinitost, mogu zahtijevati brisanje upisa i uspostavu prijašnjeg zemljišnoknjižnog stanja prema svakom stjecatelju, neovisno o rokovima koje zakon propisuje za podnošenje brisovne tužbe. Zbog toga svaki stjecatelj koji u roku u kojem je odgođena primjena pravila o zaštiti povjerenja u istinitost stječe pravo na nekretnini, mora uzeti u obzir mogućnost da njegovo pravo zbog nevaljanog upisa njegova prednika može biti izbrisano na zahtjev oštećenog nositelja knjižnog prava, te da ta mogućnost postoji sve dok ne protekne rok u kojem je odgođena zaštita povjerenja u istinitost. ${ }^{12}$ Ovakvo je stanje u sustavima umjerene zaštite povjerenja, gdje je i bez propisane odgode povjerenja $\mathrm{u}$ istinitost zemljišne knjige, stjecanje temeljem povjerenja $\mathrm{u}$ istinitost zemljišne knjige uvjetno sve dok ne isteknu rokovi (od zahtijevanja prednikove uknjižbe) u kojima je moguće i protiv savjesnog stjecatelja osporavati nevaljanost upisa njegova prednika. ${ }^{13} \mathrm{~S}$ druge strane, odgodu primjene pravila o zaštiti povjerenja

11 Josipović, T.: Zemljišnoknjižno pravo, Informator, Zagreb, 2001., str. 250. - 252.; Jug, J.: Zaštita povjerenja u zemljišne knjige u normativi i sudskoj praksi, u: Begić, S. et.al.: Zakon o vlasništvu i drugim stvarnim pravima i Zakon o zemljišnim knjigama: 1997. - 2017.: hrvatsko stvarno pravo de lege lata i de lege ferenda, Zagreb, 2017., str. 109. - 113.

12 Usp. Baran, K.; Baran, M. i Zagrajski, S.: Neka pitanja i dvojbe oko bračne stečevine i načela povjerenja u zemljišne knjige - kroz sudsku praksu, Pravni vjesnik 23 (3-4): 2006., str. 68.

13 V. Josipović, T.: Stjecanje stvarnih prava na nekretninama na temelju povjerenja u zemljišne knjige, Zb. Pravnog fakulteta Sveučilišta u Rijeci, v.19., 2/1998., str. 457. 
$\mathrm{u}$ istinitost, $\mathrm{u}$ sustavima apsolutne zaštite povjerenja ${ }^{14} \mathrm{u}$ kojima je propisano da se brisovna tužba protiv savjesnih osoba ne može podnijeti uopće, dakle tamo gdje se upisi savjesnih stjecatelja ne mogu osporavati jer su učinci povjerenja u istinitost zemljišne knjige momentalni, treba tretirati kao pružanje mogućnosti za podizanje brisovne tužbe protiv svih, pa i savjesnih stjecatelja, u rokovima $\mathrm{u}$ kojima vrijedi odgoda učinaka povjerenja u istinitost zemljišne knjige. Naravno ako zakon takvu odgodu propisuje.

Što se, pak, odgode zaštite povjerenja u potpunost zemljišne knjige tiče, u razdoblju dok traje odgoda povjerenja u potpunost moguće je zahtijevati upis neupisanih prava protiv svakog upisanog stjecatelja knjižnog prava, neovisno o tome je li on u pogledu zemljišnoknjižnog stanja bio savjestan. ${ }^{15}$ Izvanknjižni nositelji prava na nekretninama zaštićeni su tako od mogućnosti da izgube svoja nevaljano upisana ili neupisana prava zbog djelovanja pravnih učinaka zaštite povjerenja u potpunost.

U pravnim sustavima u kojima je zemljišna knjiga neažurna, odgađanje učinaka pravila o povjerenju u zemljišne knjige ima prvenstveno javnopravni interes: omogućiti uknjižbu i ažuriranje faktičnog i zemljišnoknjižnog stanja u odnosu na zemljište upisano kao društveno vlasništvo, a u vezi s brisanjem tog vlasništva zbog usklađivanja s promjenama nastalim pretvorbom društvenog vlasništva, ${ }^{16}$ kao i zaštitom statusa nekretnina s karakterom općeg i javnog dobra, ali i sprječavanjem rizika od odgovornosti države za naknadu štete. ${ }^{17}$

Sama okolnost da se radi o „odgodi,“ odnosno „prijelaznom roku,“ sugerira da to razdoblje traje relativno kratko, tj. da treba biti svedeno na najkraće moguće vrijeme unutar kojeg će se postići učinak koji je namjeravan. Samim time, činilo bi se da tema odgode učinaka pravila o povjerenju u zemljišne knjige (javnu evidenciju nekretnina) nije više aktualna u $\mathrm{BiH}$ budući da su zakoni koji propisuju načelo povjerenja u zemljišnu knjigu - važeći već značajno razdoblje. Međutim, kako će pokazati analiza entitetskih propisa, odgođeni učinak, ako se na taj način

14 Njemački i švicarski pravni poredak, čija rješenja su preuzeta i u pravni poredak entiteta (iako u donekle „čudnoj“ kombinaciji u ZSP RS). V. i u Povlakić, M. Načelo povjerenja u zemljišnu knjigu u najnovijoj praksi Vrhovnog suda Federacije BiH, NPR 1/2014., str. 45. Mulabdić, S., Mutapčić, H.: Dobrovoljno opterećenje prava vlasništva na nekretnini tuđim stvarnim pravom, Domaća i strana sudska praksa, br. 83/2020, str. 76.

16 Ovako i Josipović, T.: Zemljišnoknjižno pravo, op. cit., str. 252.

17 U Republici Hrvatskoj se kao razlog produženja rokova u kojima će vrijediti odgoda povjerenja u zemljišne knjige navodio i „izražen rizik od odgovornosti Republike Hrvatske za naknadu štete koja može nastupiti” (Prijedlog izmjena Zakona o vlasništvu iz 2009. (Nar. nov., br. 153/09), navedeno prema Milaković, G. Prestanak važenja odgode povjerenja u zemljišne knjige, Informator br. 6460, od 6. 3. 2017. g.). 
shvate završne odredbe ZSP FBiH/RS, mogao bi biti važeći status načela povjerenja u zemljišnu knjigu/javnu evidenciju.

ZV BD BiH i ZRZPZ BD BiH ne propisuju odgodu učinaka načela povjerenja u zemljišnu knjigu, bez obzira na podatke na kojima je uspostavljena evidencija prava na nekretninama. ${ }^{18} \mathrm{Na}$ taj način, još od 2001. godine, u $\mathrm{BD} \mathrm{BiH}$ načelo povjerenja u registar zemljišta proizvodi sve učinke, u oba pravca i u odnosu na sve nekretnine (čl. 8. ZRZPZ BD BiH, čl. 34. ZV BD BiH), s tim što je u BD BiH, po uzoru na pravna pravila zemljišnoknjižnog prava i zemljišnoknjižno pravo Republike Hrvatske, povjerenje u istinitost zemljišne knjige u svakom slučaju uvjetno dok ne proteknu rokovi u kojima se i protiv savjesnih osoba može brisovnom tužbom osporavati neistinit zemljišnoknjižni upis (čl. 128. ZRZPZ BD BiH).

\subsection{Završne odredbe entitetskih zakona o stvarnim pravima i odgoda povje- renja u zemljišne knjige}

Unatoč tome što su potrebu propisivanja odgođenog djelovanja pravila o povjerenju u zemljišne knjige zakonodavci redovno prepoznali, samo normiranje odgode povjerenja nije izvedeno najuspješnije, i to kako u $\mathrm{BiH}$ (RS i FBiH), tako ni u Republici Hrvatskoj (RH). Javile su se brojne dileme u primjeni odgode povjerenja u zemljišnu knjigu, jer zakonodavci nisu pravilno i nedvosmisleno normirali rokove odgode povjerenja, predmet odgode povjerenja (je li odgođeno samo povjerenje $\mathrm{u}$ istinitost ili i povjerenje u potpunost, odnosno je li odgođeno djelovanje povjerenja u odnosu na sve nekretnine ili samo na nekretnine u društvenom vlasništvu), a onda posebno, pojavilo se i pitanje predstavljaju li određene odredbe suspenziju primjene načela povjerenja u zemljišnu knjigu ako to ne propisuju izravno nego pozivaju vanknjižne titulare prava na nekretninama da upišu svoja prava. Dakle, kada govorimo o odgodi primjene načela zaštite povjerenja $\mathrm{u}$ istinitost i potpunost zemljišnih knjiga, tada treba voditi računa o roku u kojem ta odgoda proizvodi pravne učinke i na koje se nekretnine ta odgoda odnosi. ${ }^{19}$

Entitetski zakoni o stvarnim pravima u završnim odredbama sadrže određene norme čija je svrha i cilj s aspekta učinaka povjerenja u zemljišnu knjigu - diskutabilna. ZSP RS u temeljnom tekstu iz 2008. ${ }^{20}$ propisivao je u članku 346. da vanknjižni nositelji stvarnih prava mogu u roku od tri godine pokrenuti postupak za

18 V. Abdić, A. Načelo povjerenja u zemljišne knjige u Bosni i Hercegovini, Zagrebačka pravna revija, 6 (1) 2017., str. 107.

19 Milaković, G.: loc. cit.

20 Službeni glasnik RS br. 38/2008 od 27. 12. 2008. 
upis stvarnih prava u pogledu nekretnina i svih promjena na njima u zemljišnu knjigu (st. 1.), da je državno pravobraniteljstvo dužno u roku od tri godine od dana stupanja na snagu zakona pokrenuti postupke za upis stvarnih prava na nekretninama kojih je nositelj RS, jedinica lokalne samouprave, kao i upis javnih i općih dobara (st. 2.), te u stavku 3. odgodu djelovanja načela povjerenja u istinitost i potpunost zemljišnih knjiga u odnosu na stjecanja do kojih dođe unutar roka od tri godine od dana stupanja na snagu zakona, ako se njime stječe nekretnina na kojoj je bilo upisano društveno vlasništvo, a nije brisano prije stupanja na snagu zakona. Prednja odredba na izravan način suspendira učinke povjerenja u zemljišnu knjigu do 5. siječnja 2012. godine (i to, kako u pogledu istinitosti upisa, tako i u pogledu potpunosti publiciranog stanja) za nekretnine koje su bile u društvenom vlasništvu (a društveno vlasništvo nije izbrisano do stupanja na snagu ZSP-a). Otuda je stav nekih autora o trogodišnjoj odgodi povjerenja u zemljišne knjige u RS-u bio utemeljen, ${ }^{21}$ iako nije pravljena nužna razlika između nekretnina u društvenom vlasništvu (na dan stupanja na snagu ZSP RS) i nekretnina u privatnom vlasništvu (čl. 346. st. 3. ZSP RS). Međutim, Zakonom o izmjenama i dopunama Zakona o stvarnim pravima iz 2011. (dalje i: ZID ZSP 2011.)22 umjesto naprijed citirane odredbe čl. 346. usvojena je potpuno nova odredba koja propisuje da nositelji prava vlasništva koji nisu upisani u javnu evidenciju $\mathrm{u}^{23} \mathrm{o}$ nekretninama i pravima na njima mogu u roku od tri godine od dana stupanja na snagu tog zakona pokrenuti postupak pred nadležnim sudom za stjecanje pravne osnove za upis tih prava (st. 1.), zatim da su nositelji prava upravljanja, korištenja ili raspolaganja na nekretninama u društvenom, odnosno državnom vlasništvu, koji nisu upisani u javnu evidenciju o nekretninama i pravima na nekretninama, dužni u roku od tri godine od stupanja na snagu zakona pred nadležnim sudom pokrenuti postupak za stjecanje pravne osnove za upis prava vlasništva (st. 2.), te u stavku 3. da je nadležno pravobraniteljstvo dužno u roku od tri godine od dana stupanja na snagu ovog zakona pokrenuti postupak za upis neupisanih javnih i općih dobara u javnu evidenciju o nekretninama i pravima na njima. U ovom zakonu ne spominje se više izrijekom odgoda povjerenja u zemljišne knjige, pa ostaje diskutabilno jesu li novom odredbom čl. 346. st. 3. ZSP RS produženi rokovi odgode povjerenja u javnu evidenciju u odnosu na nekretnine upisane kao društveno vlasništvo, odnosno je li ovim izmjenama propisana i odgoda povje-

$21 \quad$ Mutapčić/Brkić: op. cit., str. 159. - 162.; Medić, D: Prelazne i završne odredbe Zakona o stvarnim pravima Republike Srpske, Godišnjak fakulteta pravnih nauka, Banja Luka, br. 8/2018, str. 30. - 31.; kao i kod istog autora u Novo stvarno pravo Republike Srpske, Godišnjak fakulteta pravnih nauka Apeiron, br. 1/2011, str. 12. - 14. knjigu“ zamjenjuju riječima „javnu evidenciju“ u odgovarajućem padežu. 
renja u potpunost javne evidencije u odnosu na sve ostale nekretnine (st. 1. i 2.), koja odgoda povjerenja bi tada za sve nekretnine vrijedila do 30. rujna2014. godine. ${ }^{24}$ Konačno, Zakonom i izmjenama i dopunama Zakona o stvarnim pravima RS-a iz 2015. (dalje i: ZID ZSP 2015) ${ }^{25}$ izmijenjen je ponovno članak 346. ZSP RS na način da su riječi „, roku od tri godine od stupanja na snagu ovog zakona“ zamijenjene riječima „do stupnja na snagu katastra nepokretnosti, osnovanog u skladu sa Zakonom o premjeru i katastru nepokretnosti Republike Srpske“.

I odredbom članka 361. ZSP FBiH propisuje se obveza izvanknjižnih nositelja stvarnih prava da u roku od tri godine pokrenu postupak za upis stvarnih prava glede nekretnina i svih promjena na njima u zemljišnu knjigu, ali zakon ne propisuje izričito odgađanje učinaka pravila o povjerenju u zemljišnu knjigu. Stoga će od odgovora na postavljena pitanja u vezi tumačenja važećeg ZSP RS-a, izravno ovisiti i tumačenje odredbe čl. 361. ZSP FBiH.

Osim toga, komplementarne odredbe čl. 345. ZSP RS-a i čl. 360. ZSP FBiH propisuju da rokovi za podizanje brisovne tužbe propisane tim zakonima počinju teći od dana stupanja na snagu tih zakona. Imajući u vidu da dok teče rok za podizanje brisovne tužbe, učinci povjerenja u zemljišnu knjigu ne nastupaju, te je stjecanje stvarnih prava uvjetno, to su i ove završne odredbe u izravnoj vezi s djelovanjem povjerenja u zemljišnu knjigu.

\section{Dileme u pogledu primjene završnih odredaba entitetskih zakona o stvarnim pravima}

U pravnoj teoriji je sporno predstavlja li uopće odredba o ostavljanju zakonskog roka unutar kojeg se propisuje obveza/mogućnost pokretanja postupaka radi upisa neupisanih vanknjižno postojećih stvarnih prava na nekretninama odgodu učinaka povjerenja u zemljišnu knjigu ${ }^{26}$, a potom, ako se prihvati da predstavlja takvu odgodu, treba li biti tumačena kao odgoda samo povjerenja $\mathrm{u}$ potpunost, ili samo povjerenja $\mathrm{u}$ istinitost, ili derogira povjerenje u zemljišne

$24 \quad$ ZID ZSP RS 2011. stupio je na snagu 30. rujna 2011.

25 Službeni glasnik RS br. 60/11 od 30. srpnja 2015.

26 V. stavove izražene u: Giunio, M., A.: Ustavnosudska derogacija povjerenja u zemljišne knjige - ozbiljno upozorenje na derogaciju ustavne uloge Vrhovnog suda, u Liber amicorum in honorem Jadranko Crnić (1928. - 2008.), Novi informator, Zagreb, 2009., str. 610.; zatim: Gavella, N.: Neka razmišljanja o zaštiti povjerenja u pravnom prometu, U povodu nekih sudskih i ustavnosudskih odluka, Informator, br. 5712, 2008., str. 13. Slično i u Izdvojenom mišljenju dvoje sudaca Ustavnog suda $\mathrm{RH}$ u predmetu tog suda broj U-III/821/2007 od 18. lipnja 2008. (Narodne novine br. 78/08 od 7. srpnja. 2008.), detaljnije infra $u$ tekstu o odgodi povjerenja u Republici Hrvatskoj. 
knjige u oba pravca. U prilog tome da prednja odredba propisuje odgodu učinaka povjerenja u javnu evidenciju govori logično tumačenje kako bi bilo proturječno da zakonodavac propisuje obvezu/omogućava vanknjižnim nositeljima da upišu svoja prava na nekretninama, a istovremeno im onemogućuje da tu obvezu i izvrše, što bi bio slučaj ako bi povjerenje u potpunost i istinitost zemljišne knjige nastupilo bez odgode. ${ }^{27,}{ }^{28}$ Kako se tužbom za utvrđenje izvanknjižno postojećih prava na nekretninama ne osporava postojeći upis kao neistinit, sa zahtjevom za povrat u prijašnje knjižno stanje (jer podnositelj tužbe nije raniji nositelj knjižnog prava nego izvanknjižni vlasnik), što je karakteristika brisovne tužbe koja djeluje samo na pozitivni aspekt povjerenja u zemljišne knjige - ne bi se radilo o odgodi učinaka povjerenja u istinitost. Ovom odredbom se omogućuje upis vanknjižno postojećih prava na nekretninama (vlasništva, korištenja, upravljanja i raspolaganja), što bi značilo „upotpunjavanje zemljišne knjige/javne evidencije,“ te time derogaciju djelovanja povjerenja u potpunost. ${ }^{29}$

S druge strane, oni koji smatraju da se u slučaju propisivanja obveze/mogućnosti pokretanja sudskih postupaka za upis vanknjižno postojećih prava u određenom roku ne radi o propisivanju odgode povjerenja u zemljišnu knjigu, osporavaju i tumačenja da se u tom slučaju radi o odgodi povjerenja u potpunost. Kao argument se navodi da, budući da se kod stjecanja s povjerenjem u potpunost radi o stjecanju nekretnine neopterećene tuđim pravima, teretima ni ograničenjima koja u tom trenutku nisu upisana, niti je bilo vidljivo da je njihov upis zatražen (čl. 56. st. 2. ZSP FBiH/RS), ako se prihvati da se radi o derogaciji povjerenja u potpunost javne evidencije, vanknjižno vlasništvo, odnosno suvlasništvo, bi se de facto tretiralo kao teret na upisanom vlasništvu u korist drugog titulara, što znamo da nije točno. ${ }^{30}$

V. Josipović, T. i Ernst. H. u Uloga zemljišnih knjiga u pravnom prometu bračnom stečevinom, u Kačer, H.; Momčinović, H.; Žuvela, M. (ur.), Liber amicorum in honorem Jadranko Crnić (1928. - 2008.), Novi informator, Zagreb, 2009., str. 582. (dalje se citira: Josipović/Ernst: Uloga zemljišnih knjiga u pravnom prometu bračnom stečevinom).

ZSP RS ne propisuje jedinstveno obvezu vanknjižnim nositeljima prava na nekretninama da upišu svoja prava (pokrenu sudske postupke radi stjecanja osnova za upis), nego samo nositeljima prava korištenja, raspolaganja i upravljanja na nekretninama u društvenom vlasništvu koja prava nisu upisana u javnu evidenciju, kao i nadležnom pravobraniteljstvu u odnosu na nekretnine koje predstavljaju javno i opće dobro, dok se ostalim titularima samo ostavlja mogućnost da u određenom roku pokrenu te postupke. Treba li i u tom pravcu praviti razliku između djelovanja povjerenja u odnosu na nekretnine u društvenom vlasništvu i one u privatnom vlasništvu?

Usp. Josipović/Ernst: Uloga zemljišnih knjiga u pravnom prometu bračnom stečevinom, str. 582.

Vidi argumentaciju u Giunio, M., A.: Ustavnosudska derogacija povjerenja u zemljišne knjige - ozbiljno upozorenje na derogaciju ustavne uloge Vrhovnog suda, u Liber ami- 
Usporedna analiza, izvršena u nastavku, pokazat će odgađaju li navedene završne odredbe ZSP RS/FBiH učinke povjerenja u zemljišne knjige i u kojem pravcu. Moguće je više hipoteza, ali dvije najuobičajenije su: a) ove odredbe suspendiraju primjenu načela povjerenja u zemljišne knjige u oba pravca i za sve nekretnine, $\mathrm{u}$ kojem slučaju su povjerenje u potpunost $\mathrm{i}$ istinitost zemljišne knjige $\mathrm{u} \mathrm{FBiH}$ bili odgođeni za tri godine od stupanja na snagu zakona, a u RS-u do stupanja na snagu katastra nekretnina; b) odredbe ne suspendiraju primjenu načela povjerenja u zemljišnu knjigu; ove odredbe samo pozivaju na upis vanknjižno postojećih prava na nekretninama u ostavljenom roku/zabranjuju retroaktivnu primjenu računanja rokova za brisovne tužbe, bez posljedica po djelovanje načela povjerenja u zemljišnu knjigu.

I stručna javnost u $\mathrm{BiH}$ je podijeljena po pitanju nastupa učinaka pravila o povjerenju u zemljišnu knjigu; dok jedni drže da načelo povjerenja u zemljišne knjige (u FBiH) nije odgođeno, ${ }^{31}$ drugi smatraju da je predviđena trogodišnja odgoda. ${ }^{32}$ Pitanje odgode učinaka povjerenja u zemljišnu knjigu aktualizira se kroz više sfera praktične primjene zemljišnoknjižnih i materijalnopravnih odredbi; otvorena su tako pitanja što je sa stjecanjima prava na nekretninama u RS-u u razdoblju između 30. rujna 2014. godine (kad bi, ako je vrijedila, istekla odgoda povjerenja u potpunost javne evidencije prava na nekretninama prema ZID ZSP 2011.), pa do 8. kolovoza 2015. godine kad je stupio na snagu ZID ZSP 2015., kojim se eventualno propisuje nova odgoda učinaka povjerenja u javnu evidenciju, zatim što je $s$ učincima povjerenja u zemljišnu knjigu u razdoblju između stupanja na snagu ZZK RS (2003.) i početka primjene ZSP RS (2010.), odnosno ZZK FBiH (2003.) i početka primjene ZSP FBiH (2014.). Također, postavlja se pitanje vrijede li učinci pravila o povjerenju u zemljišne knjige na područjima $\mathrm{BiH}$ gdje se vrše postupci uspostave zemljišnoknjižne/druge evidencije prava na nekretninama.

Odgođeno djelovanje načela povjerenja u zemljišne knjige bilo je predviđeno $u$ RH u ranijem Zakonu o zemljišnim knjigama iz 1996., ${ }^{33}$ te u Zakonu o vlasništvu

corum in honorem Jadranko Crnić (1928. - 2008.), Novi informator, Zagreb, 2009., str. 611.

31 Povlakić, M. (2014.): Načelo povjerenja u zemljišnu knjigu u najnovijoj praksi Vrhovnog suda Federacije BiH, NPR, br. 1/2014, str. 45.; Abdić, A., op. cit., str. 123.

32 Mutapčić, H. i Brkić, A.: op. cit., str. 159.; Babić, I. et.al. Komentar zakona o stvarnim pravima Federacije BiH, Sarajevo, 2014., str. 892.; Mulabdić/Mutapčić, loc. cit., Medić, D. Sticanje svojine od nevlasnika, Zbornik radova sa X Savjetovanja iz oblasti građanskog prava, Jahorina, 2015., str. 21. - 26. 
i drugim stvarnim pravima iz iste godine. ${ }^{34,}{ }^{35} \mathrm{U}$ ZV RH postoji izravna odredba u članku 388. st. 5. koja propisuje da se zaštita povjerenja u istinitost i potpunost zemljišnih knjiga određena tim zakonom neće primjenjivati u korist stjecanja do kojeg dođe do 1. siječnja $2017 .{ }^{36}$ ako se njime stječe nekretnina na kojoj je bilo upisano društveno vlasništvo, a nije brisano prije nego što je taj zakon stupio na snagu. Dakle, ovdje je vidljiva izričita i jasna odgoda povjerenja u zemljišne knjige (u oba pravca) u odnosu na nekretnine u društvenom vlasništvu, kakva je postojala u ZSP RS iz 2008. Osim prednje odredbe, veliku pažnju, ali i debatu stručne javnosti u RH izazvala je odredba čl. 224., st. 2. i 3. ranije važećeg ZZK RH iz 1996. kojom je bilo propisano da su izvanknjižni nositelji stvarnih prava (st. 2.), kao i državno pravobraniteljstvo (st. 3.) dužni u roku od pet godina ${ }^{37}$ od stupanja na snagu tog zakona pokrenuti postupke radi upisa stvarnih prava na nekretninama i svih promjena na njima u zemljišnu knjigu.

Dio pravne struke odredbu je tretirao kao odgodu djelovanja načela povjerenja u potpunost zemljišne knjige za sve nekretnine, za razdoblje u kojem je omogućeno podizanje tužbe za upis vanknjižno stečenih prava na nekretninama, ${ }^{38}$ dok je drugi dio smatrao da ova odredba uopće ne tangira pravnu zaštitu savjesnog stjecanja nekretnina u pravnom prometu, nego da se radi o pokušaju zakonodavca da disciplinira izvanknjižne nositelje stvarnih prava s ciljem ažuriranja zemljišnih knjiga. ${ }^{39}$

34 Pročišćeni tekst objavljen u Narodnim novinama br. 81/2015; navodi se u tekstu i kao ZV RH. O odgodi povjerenja u zemljišne knjige u RH se na jednom mjestu ovako govori: „S jedne strane može se razumjeti da RH nije uspjela izvršiti uknjižbu i usklađenje faktičnog i zemljišnoknjižnog stanja u odnosu na velik broj nekretnina koje je stekla ex lege nakon pretvorbe društvenog vlasništva, ali je s druge strane kroz dvadeset godina od donošenja ZV-a i ZZK-a u pravnom sustavu RH vladao dualizam i nejednakost u primjeni jednog od temeljnih načela stvarnog i zemljišnoknjižnog prava, a što je dovodilo do pravne nesigurnosti u pravnom prometu nekretnina." (Jug, J.: op. cit., str. 110.).

Ovaj rok odgode povjerenja bio je prvotno određen za pet godina od stupanja na snagu ZV RH, da bi kroz četiri kasnije izmjene Zakona taj rok bio produživan, a zadnja odgoda istekla je 1. siječnja 2017. godine. Vidi u Jug, J: op. cit., str. 109. - 113.

Ovaj rok je izmjenama zakona iz 2001. godine produžen za dodatnih pet godina, odnosno do 1. siječnja 2007. godine.

Vidi Josipović, T.: Stjecanje stvarnih prava na nekretninama na temelju povjerenja u zemljišne knjige, op. cit., str. 463., 464., kao i kasniji rad Josipović/Ernst: Uloga zemljišnih knjiga u pravnom prometu bračnom stečevinom, op. cit., str. 581. - 585., a ovako i u Jug, J.: op. cit., str. 113.; Baran/Baran/Zagrajski, Neka pitanja i dvojbe oko bračne stečevine i načela povjerenja u zemljišne knjige, str. 68., Milaković, G., op. cit., 2017., Ernst, H. Oštećenje vjerovnika i bračna stečevina u novoj ustavnosudskoj analizi, Zbornik PFZ, 62, (56), 2012., str. 1347.

Ovako: Giunio, A.: Derogacija povjerenja u zemljišne knjige, str. 610.; zatim: Gavella, N.: Neka razmišljanja o zaštiti povjerenja u pravnom prometu, U povodu nekih sudskih i 


\section{Odgoda povjerenja i postupak uspostave evidencije nekretnina i prava na nekretninama}

Imajući u vidu da se posljednjim izmjenama ZSP RS-a rokovi za upis vanknjižno stečenih prava na nekretninama vezuju uz stupanje na snagu katastra nekretnina kao javne evidencije nekretnina i prava na njima, bitno je odrediti kakve učinke na stjecanje i zaštitu stvarnih prava na nekretninama ima postojeća javna evidencija nekretnina, koja je važeća do stupanja na snagu katastra nekretnina (posebno imajući u vidu da katastar nekretnina ne stupa na snagu simultano za sve katastarske općine, nego parcijalno kad se pojedini postupak uspostave dovrši), te kako postupak uspostavljanja katastra nekretnina utječe na učinke povjerenja u postojeću javnu evidenciju. ${ }^{40}$

Historijski-pravno Zakon o zemljišnim knjigama iz $1930 .^{41}$ je u završnim odredbama ( $\$ 145)$ propisivao da, u područjima u kojima se zemljišne knjige tek osnivaju po novodonesenim propisima, Zakon o zemljišnim knjigama počinje važiti u pogledu svake novoosnovane zemljišne knjige danom otvaranja zemljišne knjige. ${ }^{42}$ Međutim, ZSP RS/FBiH, a ni ZPKN BD BiH ne normiraju na ovakav način odgodu primjene zakona, tim više što do osnivanja "nove“ evidencije vrijedi i primjenjuje se postojeća evidencija nekretnina i prava na nekretninama.

Dok traju postupci uspostavljanja „nove“ evidencije, nekretnine i prava na nekretninama publiciraju se u postojećem publicitetnom sustavu ${ }^{43}$ (s izuzetkom područja $\mathrm{BiH}$ gdje zemljišna knjiga još ne postoji, koji za predmet ove analize, nije relevantan). Članak 189. ZPK RS-a propisuje da se do osnivanja katastra nekretnina koriste i održavaju ranije važeće evidencije o pravima na nekretninama, dakle zemljišnoknjižna evidencija prava na nekretninama se u tom razdoblju do stupanja na snagu katastra nekretnina, vodi i održava po ZZK RS-a. Pravila ZZK

ustavnosudskih odluka, Informator, br. 5712., 2008., str. 13. Slično i u Izdvojenom mišljenju dvoje sudaca Ustavnog suda RH u predmetu tog suda broj U-III/821/2007 od 18. lipnja 2008. (Narodne novine br. 78/08 od 7. srpnja 2008.).

Vidi i čl. 55. st. 1. ZSP FBiH/RS o suspendiranju učinaka povjerenja u zemljišnu knjigu u pogledu činjeničnog stanja upisanih nekretnina.

Zakon o zemljišnim knjigama od 18. srpnja 1930. (Sl. novine Kraljevine Jugoslavije, br. 146-LIII).

V. kod Čulinović, F.: Komentar zemljišnoknjižnih zakona (Zakona o zemljišnim knjigama, o unutrašnjem uređenju, osnivanju i ispravljanju zemljišnih knjiga, te o zemljišnoknjižnim deobama, otpisima i pripisima); Beograd, 1931., str. 344., 345.

V. čl. 74. st. 1. ZPK RS (nakon izmjena i dopuna zakona iz 2016.): „Od dana početka osnivanja katastra nepokretnosti sprovode se promjene u katastarskoj evidenciji, zemljišnoj knjizi i knjigama uloženih ugovora do isteka roka za osnivanje katastra nepokretnosti određenog u javnom oglasu.“" 
RS-a o pretpostavci istinitost i potpunost zemljišne knjige, te stjecanju prava po tom temelju (čl. 9 ZZK RS) nisu izričito derogirana. S druge strane, u postupku osnivanja katastra nekretnina provodi se postupak izlaganja, te postupak utvrđivanja prava na nekretninama koje su bile u postupku izlaganja, nakon čega nadležna komisija za izlaganje donosi rješenje koje sadrži podatke o nekretninama, podatke o nositeljima prava na nekretninama, ograničenja vezana uz raspolaganje nekretninama, nalog za upis podataka o nekretninama i nositeljima prava na nekretninama (čl. 86. ZPK RS). Postupak osnivanja objavljuje se i pozivaju se zainteresirane osobe da sudjeluju u postupku. ${ }^{44}$

ZZK FBiH također propisuje postupak uspostave zemljišne knjige. ${ }^{45}$ Ovaj postupak, u ovdje razmatranom smislu, ${ }^{46}$ podrazumijeva da se na područjima Federacije $\mathrm{BiH}$ gdje je zastupljeno paralelno egzistiranje katastra zemljišta zasnovanog na novoj izmjeri i zemljišne knjige zasnovane na austro-ugarskoj izmjeri, po procedurama propisanim zakonom, na temelju raspoložive dokumentacije katastra zemljišta i zemljišne knjige, uz sudjelovanje zainteresiranih nositelja prava, vrši upis prava na nekretninama definiranim po podacima nove izmjere. ${ }^{47} \mathrm{U}$ odredbama ZZK FBiH nije predviđeno da se za vrijeme dok traje uspostava zemljišne knjige $^{48}$ suspendiraju učinci povjerenja u zemljišne knjige. Ipak, u praksi zemljiš-

${ }_{44} \quad$ U postupku osnivanja katastra nekretnina objavljuje se oglas o osnivanju i izlaganju podataka na javni uvid u javnom oglasu u katastarskoj općini u kojoj se osniva katastar nekretnina i na internetskoj stranici Republičke uprave za geodetske i imovinskopravne poslove RS (čl. 78. ZPK RS) najkasnije 30 dana prije početka izlaganja podataka i utvrđivanja prava na nepokretnostima, a u svrhu osnivanja katastra nekretnina. Tako na dan 2. 6. 2020. godine, uvidom u stanje Oglasa o osnivanju katastra nekretnina i izlaganju na javni uvid podataka o nekretninama i podataka o pravima na nekretninama (https://www.rgurs.org/ lat/oglasi-o-pojedinacnom-izlaganju) vidljivo je da je od početka 2020. u tijeku izlaganje podataka na javni uvid u više od deset općina (a u određenim administrativnim općinama $\mathrm{u}$ više katastarskih općina), te je u oglasima navedeno da se rokovi za prijavu prava na nekretninama mogu produživati.

45 Usp. Poglavlje VIII ZZK FBiH „Novo uspostavljanje, zamjena i postupak uspostavljanja zemljišne knjige“ (članci 63. - 72.) kao i s njima povezane odredbe čl. 73. i 88., ZZK FBiH, te čl. 13. Pravilnika o postupanju u zemljišnoknjižnim stvarima ( $\mathrm{Sl}$. novine $\mathrm{FBiH}$, br. 5/03) V. više u Šimić, G. i Mićanović, I.: Najbolja praksa u radu zemljišnoknjižnih ureda u Federaciji $\mathrm{BiH}$ kod procesa zamjene ili uspostave zemljišne knjige, Projekat registracije nekretnina u BiH/FBiH i CILAP, 2014., str. 1. i dalje). Vidi za primjer oglas o postupku uspostave zemljišne knjige na https://pravosudje.ba/vstv/faces/vijesti.jsp?id=58243.

Postupak uspostave za prostore gdje zemljišnoknjižna evidencija nije ranije ni postojala ili je uništena, pa se po ovim odredbama ZZK FBiH uspostavlja, nije relevantno za predmet ovog rada (ako zemljišna knjiga ne postoji - nema ni povjerenja u zemljišnu knjigu). Šimić, G. i Mićanović, I.: op. cit., str. 1. Zakon propisuje da ovaj postupak traje najduže jednu godinu (čl. 67. st. 4. ZZK FBiH), ali u praksi postupak pripreme za uspostavu i sama uspostava traju znatno duže. 
noknjižnih ureda je da na zemljišnoknjižnim izvacima koji se izdaju u vrijeme dok traje uspostava zemljišne knjige u A2 listu izvatka posebnim upisom (plombom) publiciraju da postoji prijava osnivanja zemljišnoknjižnog uloška prema podacima novog premjera (po npr. čl. 88. st. 2. ZZK FBiH), ${ }^{49}$ čime se treće osobe obavještavaju da je u tijeku taj postupak sa svojim zakonom propisanim posljedicama. ${ }^{50}$ Uspostava zemljišne knjige se objavljuje (čl. 67. ZZK FBiH).

ZRZPZ BD BiH propisuje postupak uspostave registra zemljišta i prava na zemljištu, kao jedinstvene evidencije nekretnina i stvarnih prava, koji postupak podrazumijeva izlaganje na javni uvid podataka o nekretninama (tehničkih podataka novog premjera) i utvrđivanje prava na nekretninama. ${ }^{51}$ Do stupanja na snagu registra zemljišta postojeće evidencije nekretnina ostaju na snazi. ${ }^{52}$ Postupak uspostave objavljuje se (čl. 231. ZRZPZ BD BiH). U okviru odredbi o osnivanju registra zemljišta ne suspendira se djelovanje načela povjerenja u zemljišne knjige za vrijeme dok traje postupak uspostave.

Suprotno tome, ZZK RH iz 1996., s očitom namjerom postizanja pravne sigurnosti u prometu pravima na nekretninama, u dijelu pod nazivom „Osnivanje, obnavljanje, dopunjavanje i preoblikovanje zemljišne knjige“ propisuje da dok rok za ispravak određen oglasom ne istekne, upisi u zemljišnu knjigu ne smatraju se istinitim i potpunim, pa se nitko ne može pozivati na to da je postupao s povjerenjem u njihovu istinitost, te da dok rok za ispravak ne istekne, na svim izvacima i drugim ispravama koje zemljišnoknjižni sud izdaje na osnovu podataka iz zemljišne knjige glede koje taj rok teče učinit će se to vidljivim, uz točnu oznaku zadnjega kalendarskog dana tog roka (čl. 187. ZZK RH 1996.). ${ }^{53}$

49 Sadržaj zabilježbe, tamo gdje je publicirao vođenje postupka uspostave ili predstojeći postupak uspostave, glasi npr.: „Pr. 03. 03. 2017 god. Dn. Br. 713/17. na temelju člana 88 stav 2. ZZK i prijavnog lista br. 469/17, k.č. 91/1492 odgovara parceli 2255/1 nove izmjere upisanoj u zk ul br. $586 \mathrm{KO}$ xx."

Jedna od posljedica je utvrđivanje najvjerojatnijeg titulara prava na nekretninama, a on ne mora biti onaj koji je upisan u zemljišnoj knjizi. Vidi npr. Kantonalni sud Mostar, Rješenje broj 070 Dn 01673019 Gž od 28. 5. 2020. Vidi i odluku istog suda broj: 070 Dn 016733 19 Gž od 28. 5. 2020.

51 Čl. 243. ZRZPZ BD BiH. Vidi detaljnije u: Latifović, F.: Izlaganje na javni uvid podataka o nekretninama i utvrđivanje prava na zemljištu u funkciji uspostave jedinstvenog registra zemljišta i prava na zemljištu u Brčko distriktu BiH, Geodetski glasnik god. 48, br. 45 ., 2014., str. 52.

52 Članak 260. st. 1. ZRZPZ BD BiH.

Vidi više kod Kontrec, D., Osnivanje (obnova) zemljišnih knjiga - rad katastarskog i zemljišnoknjižnog povjerenstva (de lege lata, de lege ferenda), Zbornik Pravnog fakulteta Sveučilišta u Rijeci, v. 29, br. 1., 2008., str. 19. 
Može li se otuda govoriti o stjecanju temeljem povjerenja u zemljišnu knjigu u slučaju stjecanja prava na nekretnini u vrijeme dok traje uspostava odnosne zemljišne knjige/registra zemljišta/katastra nekretnina? Pregledom dostupne sudske prakse nisu pronađene odluke sudova u Federaciji $\mathrm{BiH}$ koje bi ukazivale na stav po ovom pitanju. ${ }^{54}$ Po našem mišljenju, moguće je argumentirati u oba pravca. Zbog izostanka suprotne zakonske odredbe, učinci povjerenja u zemljišnu knjigu i u tim katastarskim općinama vrijede. Naime, iz čl. 55. st. 1. ZSP FBiH/ RS proizlazi da se samo u pogledu činjeničnog stanja nekretnine zemljišna knjiga ne smatra istinitom i potpunom ako je uspostavljena na temelju podataka starog premjera. Otuda bi podaci o nositeljima prava na ovim nekretninama uživali zaštitu povjerenja u istinitost i potpunost, a ovako bi proizlazilo i iz čl. 88. st. 1. ZZK FBiH/RS („Promjenom oznake i preuzimanjem rezultata premjera ne mijenjaju se pravni odnosi na nekretnini."). Međutim, imajući u vidu da se u slučajevima uspostave ne vrši samo preuzimanje podataka novog premjera, već se uspostavlja novi zemljišnoknjižni uložak/list nepokretnosti po podacima novog premjera, u kojem postupku se utvrđuju i prava na nekretninama, čini se opravdanim štititi i vanknjižne titulare prava na nekretninama za vrijeme dok postupak uspostave traje, kao što je to zakonodavac učinio u RH.

Imajući u vidu prezentiranu zakonsku regulativu, i usporedna rješenja, čini se da $\mathrm{u} \mathrm{BiH}$ učinci povjerenja u potpunost nisu suspendirani u ovisnosti o postupku osnivanja/uspostave „nove“ ili ažuriranja postojeće evidencije nekretnina. Ipak, u slučaju da je u zemljišnoknjižnom ulošku u određenoj katastarskoj općini izvršena zabilježba vođenja postupka uspostave, ili zabilježba da je sporno pravo vlasništva (čl. 85a) ZPK RS; čl. 238. st. 1. ZRZPZ BD BiH; ili npr. čl. 87. st. 1. ZZK $\mathrm{FBiH} / \mathrm{RS}$ ), postoje osnove za isključenje pravila o zaštiti povjerenja u zemljišnu knjigu. Savjesnost stjecatelja je pretpostavka za primjenu pravila o povjerenju u zemljišne knjige, a stjecatelj se ne može smatrati savjesnim u slučaju da je znao ili imao dovoljno razloga posumnjati da je zemljišna knjiga netočna ili nepotpuna (čl. 55. st. 2. ZSP FBiH/RS; čl. 34. st. 2. ZV BD BiH). Za vrijeme dok traje uspostava zemljišne knjige, iako iz zemljišne knjige nije moguće pouzdano utvrditi postojanje tuđih prava, tereta ni ograničenja (čl. 56. st. 2. ZSP FBiH/RS), ali zain-

$54 \quad$ Ali, iz dostupne sudske prakse moguće je ustanoviti da sudovi na odnose koji su nastali prije stupanja na snagu ZSP FBiH/RS, bez zadrške primjenjuju pravila o povjerenju u zemljišnu knjigu: v. VS FBiH: 650 P 21459115 Rev od 3. 7. 2018.; 530 P 04606915 Rev od 8. 3. 2017.; 650 P 04183815 Rev od 22. 9. 2015.; 650 P 09857716 Rev od 12. 9. 2017.; 510 P 05262418 Rev od 24. 7. 2018.; -VSRS 780 P 01821617 Rev, od 12. 10. 2017.; 800 P 026263 12 Rev od 14. 3. 2013.; 800 P 02706614 Rev od 1. 11. 2016., neobjavljeno (pribavljeno od Centra za sudsku dokumentaciju VSTV BiH). 
teresirane osobe, s obzirom na okolnosti, ${ }^{55}$ imaju dovoljno razloga posumnjati u to da stvar pripada otuđitelju.

Dakle, postoje razlozi isključenja primjene pravila o zaštiti povjerenja u zemljišnu knjigu ako do stjecanja dođe za vrijeme dok traje postupak uspostave zemljišne knjige/katastra nekretnina/registra zemljišta. Ti razlozi ne mogu se de lege lata smatrati odgodom učinaka povjerenja u zemljišnu knjigu, ali oni to ipso facto jesu jer će, gore navedenom logikom, biti moguće dokazati da je stjecatelj bio nesavjestan.

U svakom slučaju, imajući u vidu svrhu zemljišne knjige da odražava stvarno stanje nekretnina na način da je upisani titular stvarnog prava ujedno i izvanknjižni titular prava, rok ostavljen čl. 361. ZSP FBiH (koji je u FBiH istekao dana 6. ožujka 2017. godine) je posljednji zakonski modus da se zemljišna knjiga dovede $u$ stanje potpunosti. ${ }^{56}$

\section{Odgoda povjerenja $u$ istinitost?}

Odredbe čl. 345. ZSP RS i čl. 360. ZSP FBiH propisuju da rokovi za podizanje brisovne tužbe prema tom Zakonu počinju teći stupanjem na snagu tog Zakona, čime se isključuje retroaktivno računanje rokova za podizanje brisovne tužbe. Intencija zakonodavca bila je da se spriječi da trogodišnji rokovi za osporavanje prednikovog nevaljanog upisa proteknu prije nego što se osobi povrijeđenoj $\mathrm{u}$ knjižnom pravu omogući adekvatna zaštita. ${ }^{57}$ Dakle, praktična svrha odredbe čl. 345. ZSP RS i čl. 360. ZSP FBiH je neka vrsta odgode nastupanja učinaka povjerenja u istinitost zemljišne knjige, a teorijsko-pravno radi se o zabrani retroaktivnog računanja trogodišnjih rokova za podizanje brisovne tužbe. ${ }^{58}$

55 Jedna od okolnosti je i ta da se postupak uspostave najavljuje javnim oglašavanjem (v. čl. 67. ZZK FBiH, čl. 231. ZRZPZ BD BiH, čl. 74. ZPK RS).

Mulabdić, S. i Mutapčić, H.: Dobrovoljno opterećenje prava vlasništva na nekretnini tuđim stvarnim pravom, Sudska praksa domaća i strana, br. 83/2020, Privredna štampa, Sarajevo, str. 76.

Naime stupanjem na snagu ZSP RS omogućuje se stjecanje stvarnih prava temeljem povjerenja $u$ istinitost zemljišne knjige. Moguće da do tog stjecanja dođe nakon stupanja na snagu ZSP-a, ali nakon proteka više od tri godine od nevaljanog upisa stjecateljevog prednika, pa se u tom slučaju, da nema ove odredbe čl. 345. ZSP RS, prednikov upis uopće ne bi mogao osporavati.

Jug. J.: op. cit., str. 112. Josipović, T.: Stjecanje stvarnih prava na temelju povjerenja u zemljišne knjige, op. cit., str. 464. 
Ova odredba ne bi trebala izazivati dileme u pravnim sustavima u kojima je brisovna tužba (u pogledu procesne legitimacije, rokova i sadržaja) jasno definirana (v. supra 3.). U tim sustavima odgodom povjerenja u istinitost produžuju se rokovi za podizanje brisovne tužbe za onoliko vremena koliko traje propisana odgoda učinaka pravila o povjerenju u zemljišne knjige.

U entitetima je, ipak, pitanje brisovne tužbe nespretno riješeno. Npr., u odredbi čl. 56. ZSP RS rokovi za podizanje brisovne tužbe određeni su konfuzno. Odredbe stavaka 3. i 4. članka 56. ZSP RS su proturječne jer propisuju različite rokove za podizanje brisovne tužbe, ne vršeći pri tom različitom definiranju i distinkciju u odnosu na pasivno legitimirane osobe, odnosno vrste upisa koji se osporavaju u jednim ili drugim rokovima. Predviđeni su tako kao objektivni, trogodišnji, rokovi od izvršene prednikove uknjižbe i kao subjektivni šezdesetodnevni rokovi od isteka roka za žalbu protiv odluke o dozvoli prednikova neistinitog upisa, (st. 3.), ali i opisno definirani (redovno dulji) rokovi u kojima se može osporavati osnova stjecateljevog upisa, te isključenje mogućnosti podizanja brisovne tužbe uopće - protiv savjesnih trećih stjecatelja prava (st. 4.). U najkraćem, odredbe 56. st. 3. ZSP RS i 56. st. 4. (drugi dio) istog zakona jedna u vezi s drugom su neprimjenjive, jer se na jednom mjestu (čl. 56. st. 3.) dopušta brisovnu tužbu (i protiv savjesnih trećih osoba), u točno propisanim rokovima, da bi na drugom mjestu (čl. 56. st. 4.) isključio mogućnost podizanja brisovne tužbe protiv savjesnih trećih osoba. ${ }^{59}$ Dovodeći ovo u vezu s odredbom članka 345 . ZSP RS, ovisno o tome kako se tumači ova odredba, može se izvesti zaključak da povjerenje u istinitost a) de facto jeste odgođeno za razdoblje od tri godine od stupanja na snagu ZSP RS, čak i prema trećim savjesnim stjecateljima, ili b) nije odgođeno jer se protiv savjesnog trećeg po ZSP RS brisovna tužba ne može podići. Autor je skloniji potonjoj pretpostavci, a iz razloga koji slijede argumentaciju u odnosu na čl. 360 ZSP FBiH.

Budući da je i odredba čl. 360. ZSP FBiH očigledno blanketnog karaktera, potrebno ju je dovesti u vezu s odredbama tog zakona koje propisuju podnošenje brisovne tužbe, a to je jedino ${ }^{60}$ odredba čl. 56. st. 3. ZSP FBiH, koja kaže: „Bri-

59 V. Medić navodi da su odredbe ZSP RS o brisovnoj tužbi, kod postojećeg stanja stvari, unijele dosta konfuzije, da su teško primjenjive i da su bile nepotrebne (Medić, D.: Sticanje svojine od nevlasnika, op. cit., str. 26.).

Postoje i druge odredbe ZSP FBiH koje propisuju mogućnost podnošenja određenih vrsti „brisovnih zahtjeva“ radi utvrđenja da je određeni upis u zemljišnoj knjizi nevaljan kao npr. tužba savjesnog stjecatelja kod višestrukog ugovaranja otuđenja nekretnine protiv upisanog nesavjesnog stjecatelja iz čl. 57. st. 2. ZSP (da se u ovom slučaju ne radi o brisovnoj tužbi v. Babić, I. et. al., op. cit., str. 295. - 297., zatim Simonetti, P.: Višestruko 
sovna se tužba može podići u rokovima u kojima se može ostvarivati osporavanje pravnog osnova upisa, ali se ne može podići ukoliko je savjesna treća osoba pouzdavajući se u zemljišnu knjigu upisala svoje pravo.“ Dakle imamo s jedne strane blanketnu normu koja kaže da trogodišnji rokovi za podizanje brisovne tužbe počinju teći od stupanja na snagu ZSP-a, te odredbu o brisovnoj tužbi na koju blanketna norma upućuje, u kojoj se trogodišnji rok ne spominje (spominju se opisni rokovi „u kojima se može ostvarivati osporavanje pravnog osnova upisa"). ${ }^{61}$ Trogodišnji rok se istina spominje u odredbi o modusu ostvarivanja pravne zaštite savjesnog ugovaratelja kod višestrukog ugovaranja otuđenja koji se ovlašćuje podnijeti zahtjev za brisanje upisanog prava nesavjesnog ugovaratelja i uknjižbu prava vlasništva u svoju korist, međutim u ovom slučaju ne radi se o brisovnoj tužbi, nego kvazi-brisovnoj tužbi, odnosno vrsti vlasničke tužbe. ${ }^{62}$ Odredba čl. 360. otuda je nejasna budući da ostaje nedorečeno zašto zakonodavac posebnom odredbom, i to na ovom mjestu u zakonu, propisuje početak tijeka roka (i to drugačijeg) za podizanje brisovne tužbe kad je to već prije učinio odredbom članka 56. ZSP FBiH? Prethodno izvršena analiza odredbe čl. 56. ZSP RS pokazuje, uz ostale rezultate, i to da tamo, ovaj trogodišnji rok, stoji barem u vezi s odredbom čl. 56. st. 3. ZSP RS. Valja imati u vidu da je Nacrt Zakona o stvarnim pravima FBiH sadržavao identičnu odredbu o brisovnoj tužbi kakva postoji u čl. 56. st. 3. ZSP RS, ${ }^{63}$ a koja je u finalnoj verziji teksta zakona izbačena.

ugovaranje otuđenja, op. cit., str. 32.) kao i npr. zahtjev za brisanje društvenog/državnog vlasništva, te upis prava vlasništva u korist ranijeg nositelja prava korištenja na građevinskom zemljištu (čl. 343. ZSP), koji također ne potpada pod kategoriju brisovne tužbe iz prostog razloga jer se radi o zahtjevu u vanparničnom, zemljišnoknjižnom postupku.

Neki autori korelaciju odredbi čl. 56. st. 3. i čl. 360. ZSP FBiH vide na način da potonja odredba nadopunjuje prvu budući da u prvoj nisu decidno propisani rokovi za podnošenje brisovne tužbe, pa da iz odredbe čl. 360. „slijedi da rok za podnošenje brisovne tužbe iznosi 3 godine.“ (Babić, I. et .al., op. cit., str. 289., 290.). S prednjim stavom teško bi se bilo složiti iz više razloga. Prvo, protivi se pravilima logičkog tumačenja, kao i nomotehnike, normu završnih odredbi zakona shvaćati kao sredstvo definiranja roka podnošenja brisovne tužbe, koji institut nastavlja postojanje i nakon što završne odredbe zakona odavno izgube relevantnost. Drugo, nije točno da rokovi za podnošenje brisovne tužbe u ZSP $\mathrm{FBiH}$ nisu propisani, oni su samo umjesto eksplicitno - brojkom, definirani opisno, upravo odredbom čl. 56. st. 3. ZSP. Treće, gubi se iz vida tekst Nacrta ZSP FBiH koji je uistinu predviđao trogodišnje rokove za podizanje brisovne tužbe (kao u čl. 56. st. 3. ZSP RS).

Vidi u: Šago, D. i Radić, Z.: Brisovna tužba - zaštita knjižnih prava, Zbornik Pravnog fakulteta Sveučilišta u Rijeci (1991.) v. 38/1, 2017., str. 479., kao i Čizmić, J., Šago, D. i Kačer, B.: Osnove zemljišnoknjižnog prava, University of Maribor Press, 2018., (e-knjiga), str. 634. - 637.

V. Babić, I. et. al., op. cit., str. 891.; Povlakić, M.: Transformacija stvarnog prava u Bosni i Hercegovini, op. cit., str. 122. 
Slijedom prednjeg, budući da ta odredba predstavlja regulaciju „tradicionalne“ brisovne tužbe protiv savjesnih stjecatelja (kakva je postojala u ranijim pravnim pravilima zemljišnoknjižnog prava), a potom je iz novog stvarnog prava izbačena, proizlazi da je cilj odredbe čl. 360. ZSP FBiH - zaštita ranijih nositelja knjižnih prava koji su povrijeđeni u svom pravu neistinitim upisom u korist prednika nesavjesnog stjecatelja, od nastupanja prekluzije u mogućnosti korištenja brisovne tužbe radi osporavanja tog neistinitog upisa. ${ }^{64}$ Dakle, odredba čl. 360. ZSP $\mathrm{FBiH}$ odnosi se na početak tijeka rokova za podnošenje brisovne tužbe protiv nesavjesnih stjecatelja jer je samo protiv takvih stjecatelja brisovnu tužbu moguće podići (čl. 56. st. 3. ZSP FBiH). Propisivanje trogodišnjeg roka u ovoj odredbi samo je tehnička greška ${ }^{65}$ nastala vjerojatno kao rezultat propusta da se odredba uskladi s rezultatima rasprave o Nacrtu ZSP-a, kad je iz članka 56. Nacrta ZSP FBiH izbrisana odredba stavka 3. (koji je sadržajno odgovarao čl. 56. st. 3. ZSP RS) ${ }^{66}$ Zakonodavac je, imajući u vidu da se brisovna tužba podnosi zbog neistinitosti prednikova upisa, u rokovima koji se računaju od provođenja prednikova neistinitog upisa, koji rokovi su lako mogli isteći i prije stupanja na snagu ZSP-a, upravo i predvidio da rokovi za podnošenje brisovne tužbe počinju teći tek stupanjem na snagu ZSP-a.

64 Usporedi: drugačije Velić, L. u Babić, I. et.al. Komentar zakona o stvarnim pravima Federacije BiH, Sarajevo, 2014., str. 891. („Ovom odredbom se nastojalo što prije doći do stvarnog nosioca stvarnih prava na nekretninama, te u skladu s tim izvršiti ažuriranje javnih registara i stvoriti pretpostavke za siguran pravni promet. Cilj zakonodavca je pri tome mogao zanemariti pravne učinke ovakve odredbe, te činjenicu da bi po isteku roka došlo do legalizacije protivpravnog prisvajanja tuđe imovine.“).

Rokovi u kojima se može vršiti osporavanje osnova upisa, kako ZSP FBiH definira rokove unutar kojih je moguće podići brisovnu tužbu, nisu nužno trogodišnji. Ove rokove propisuju posebni, materijalnopravni zakoni (npr. uslijed razloga pobojnosti ugovor se može osporavati u objektivnom roku od tri godine od zaključenja ugovora - čl. 117. Zakona o obveznim odnosima, a uslijed razloga ništavosti ugovori se mogu pobijati bez vremenskog ograničenja - čl. 110. Zakona o obveznim odnosima; sudske odluke se mogu po vanrednim pravnim lijekovima osporavati u roku od pet godina od pravomoćnosti, odnosno bez vremenskog ograničenja ako kojoj stranci nezakonitim postupanjem nije bila data mogućnost da raspravlja pred sudom; ili ako je u postupku kao tužitelj ili tuženik sudjelovala osoba koja ne može biti stranka u postupku, ili ako stranku koja je pravna osoba nije zastupala ovlaštena osoba, ili ako parnično nesposobnu stranku nije zastupao zakonski zastupnik, ili ako zakonski zastupnik odnosno punomoćnik stranke nije imao potrebna ovlaštenja za vođenje parnice, ili za pojedine radnje u postupku, ako vođenje parnice, odnosno obavljanje pojedinih radnji u postupku nije bilo naknadno odobreno (čl. 255. 257. Zakona o parničnom postupku FBiH, Službene novine FBiH br. 53/2003, 73/2005, 19/2006 i 98/2015) itd. 
Kad se radi o potencijalnom utjecaju odredbi čl. 360. ZSP FBiH, odnosno 346. ZSP RS, na povjerenje u istinitost zemljišne knjige, ne mogu se zanemariti odredbe koje propisuju da se u FBiH i RS brisovna tužba ne može podići protiv savjesne treće osobe koja je svoje pravo upisala u zemljišnu knjigu (čl. 56. st. 3. ZSP FBiH, čl. 56. st. 4. ZSP RS). Prijelazne odredbe ne derogiraju tu odredbu. U duhu je ZSP-a tumačenje da se njime štite savjesne osobe, savjesni stjecatelji, a ne štite nesavjesni. ${ }^{67}$ Stoga smatramo da je svrha odredbe čl. 360 ZSP FBiH, odnosno čl. 345. ZSP RS, spriječiti nastup prekluzije za podizanje brisovne tužbe (a ujedno i onemogući retroaktivnu primjenu roka za brisovnu tužbu) samo u odnosu na nesavjesne treće stjecatelje. Prednje ne bi bilo novina u stvarnopravnom sustavu Federacije i RS-a, s obzirom da kontekstualno sličnu odredbu sadrži i ZZK FBiH/ RS. ${ }^{68}$

Međutim, u RS-u, kod izričite odredbe o mogućnosti podizanja brisovne tužbe u rokovima iz čl. 56. st. 3. ZSP RS, ima prostora i za drugačiju argumentaciju. Upravo kod reguliranja mogućnosti osporavanja zemljišnoknjižnih upisa vidljive su sve loše strane nekritičke transplantacije pravnih rješenja iz više različitih pravnih sustava u pravni sustav države primateljice. ${ }^{69}$ Konkretno, preuzimanje rješenja iz austrijskog stvarnopravnog sustava (brisovne tužbe iz čl. 56. st. 3. ZSP RS) i njemačkog stvarnopravnog sustava (ispravke neispravnog upisa iz čl. 60. ZZK RS i čl. 56. st. 4. ZSP RS) dovodi do nejasnoća glede momenta nastupa učinaka povjerenja u istinitost zemljišne knjige, pa otuda i glede eventualne odgode tih učinaka.

\section{Zaključak}

Odgoda učinaka pravila o povjerenju u zemljišnu knjigu u prijelaznom razdoblju, iako motivirana opravdanim razlozima, ne djeluje u pravcu afirmacije načela povjerenja jer u tom razdoblju izvanknjižni vlasnici zbog nepoznavanja

67 Vidi kod Babić, I. et. al., op. cit., str. 297.

Članak 60. st. 2. ZZK FBiH/RS predviđa0 nezastarivo pravo da se traži ispravka zemljišne knjige, i to po odobrenju upisane osobe, koje odobrenje može zamijeniti sudska odluka povodom pravnog sredstva koje se naziva tužba za davanje odobrenja. Iako to ne proizlazi direktno iz zakonske odredbe, smatra se da se, u vezi sa čl. 9. ZZK FBiH, te čl. 56. st. 3. ZSP $\mathrm{FBiH}$, ispravka ne može tražiti ako je treća savjesna osoba stekla neko pravo na temelju pogrešne zemljišne knjige. V. u Povlakić, M. u Babić, I. et. al., op. cit., str. 297.

Vidi više kod: Teubner, G.: Legal irritants: Good faith in British law or how unifying law ends up in new divergences, u: The Modern law review, Vol. 61, No. 1 (1998), str. 17. - 24. 
zemljišnoknjižnog stanja, nepoznavanja pravnih propisa, nezainteresiranosti i dr., rijetko upisuju svoja izvanknjižno stečena prava, tako da i ne dolazi u tom smislu do usklađivanja izvanknjižnog i zemljišnoknjižnog stanja. ${ }^{70}$ Iz novog stvarnopravnog i zemljišnoknjižnog prava u $\mathrm{BiH}$ jasno je vidljiva orijentiranost $\mathrm{k}$ postizanju ažurne javne evidencije o pravima na nekretninama i posljedičnoj zaštiti sigurnosti prometa nekretninama; pa ostavljanje neodređenog roka za upis vanknjižno stečenih prava na nekretninama ne služi cilju zakona. Naprotiv, upravo primjena pravila o povjerenju u zemljišnu knjigu, zbog prijetnje gubitkom neuknjiženog stvarnog prava, motivira vanknjižne nositelje da upisuju prava na nekretninama. ${ }^{71}$ Stoga, najpravilniji bi bio zaključak da propisivanje obveze upisa vanknjižno stečenih prava na nekretninama u javnu evidenciju u određenom razdoblju ne predstavlja samo po sebi odgodu načela povjerenja u potpunost te javne evidencije budući da tako nešto nije ni propisano, ali da činjenica uspostavljanja, osnivanja javne evidencije prava na nekretninama, ako je publicirana, može utjecati na savjesnost stjecatelja u smislu da je imao dovoljno razloga posumnjati u to da stvar pripada otuđitelju.

U dostupnoj sudskoj praksi koja se odnosi na primjenu načela povjerenja u zemljišne knjige, ${ }^{72}$ sporni odnosi nastali su prije stupanja na snagu ZSP FBiH/RS, pa se ne spominje odgoda učinaka pravila o povjerenju u zemljišnu knjigu, već se načelo primjenjuje ako se smatra da su ispunjene zakonske pretpostavke za isto. Slijedom prednjeg, bilo bi i u tom pravcu kontraproduktivno, ali i protivno pravnoj sigurnosti da nakon gotovo desetogodišnje primjene pravila o zaštiti povjerenja u zemljišnu knjigu nakon stupanja na snagu ZSP-a povjerenje u zemljišne knjige u entitetima bude odgođeno.

Postupci uspostave zemljišne knjige/katastra nekretnina su postupci kojima je cilj uspostaviti evidenciju nekretnina prema podacima tzv. novog premjera i pri tom ažurirati podatke o nositeljima stvarnih prava na nekretninama. Za razdoblje dok u odnosu na određene katastarske općine, ili čestice, traje uspostava zemljišne knjige, postoje okolnosti koje mogu dovesti do derogacije učinaka povjerenja $\mathrm{u}$ istinitost i potpunost te zemljišne knjige, jer se u tom slučaju može dokazivati da ne postoji savjesnost stjecatelja u pogledu ispravnosti zemljišne knjige. U tim slučajevima ne radi se o odgodi učinaka povjerenja u zemljišnu knjigu, nego o postojanju jedne od smetnji za zaštitu povjerenja u zemljišnu knjigu, a to je nesavjesnost stjecatelja.

$70 \quad$ Abdić, A., op. cit., str. 122., Mutapčić/Brkić, op. cit., str. 161.

71 V. Mutapčić/Brkić, op. cit., str. 161.; Povlakić, M.: Načelo upisa i stjecanje prava vlasništva na nekretninama prema novom zemljišnoknjižnom i stvarnom pravu u BiH, Godišnjak Pravnog fakulteta u Sarajevu, LIII - 2010., str. 326. 


\section{DELAY OF THE PUBLIC TRUST PRINCIPLE IN LAND REGISTERS IN BOSNIA AND HERZEGOVINA?}

Summary: The final provisions of the entity Laws on Real Rights invite/order non-registered holders of real rights to real estate to register their rights within the deadlines prescribed there, and stipulate that deadlines for filing an action for cancelation begin to run only after the entry into force of these laws. These provisions can, comparatively legally grounded, be interpreted as delaying the effects of the rules on trust in land registers. On the other hand, before the enactment of the Law on Real Rights, the Laws on Land Registers provide for the protection of the acquisition of real rights on real estate based on trust in the land register, without leaving a transitional deadline for harmonizing the land registry with the unregistered rights on real state, in which period the effects of trust in the land registers would not be valid. Hence, it seems contradictory that the principle of trust in land registers operates in the period after the adoption of the Land Registry Act and until the entry into force of the Real Rights Act, after which its effects are suspended. This paper analyzes potential obstacles to the effects of trust in land registers in the entities and the Brčko District of BiH (such as the procedure for establishing a land registry / real estate cadaster), and attempts to prove that in $\mathrm{BiH}$, since the entry into force of the reformed land registry legislation, the effects of trust in land registers has not been delayed (except in Republika Srpska in the period 2010-2011, but only regarding real estate in social ownership).

Key words: principle of public trust in land registers, delay of public trust, establishment of land register. 